\title{
Three New and Two Confirmed Records for the Iraqi Spider Fauna (Arachnida: Araneae)
}

\author{
Azhar Mohammed AL-KHAZALI I, ${ }^{*}$, Fenik Sherzad HUSSEN ${ }^{2}$, Hamid Saeid KACHEL ${ }^{3}$, Noora Khalid \\ ISMAIL $^{3}$, Ayoub Ibrahim AHMED ${ }^{4}$
}

\author{
${ }^{1}$ University of Sumer, College of Basic Education, Department of Science, Branch Biology, Dhi Qar, Iraq \\ ${ }^{2}$ Salahaddin University, College of Science, Department of Biology, Erbil, Iraq \\ 3 University of Zakho, College of Basic Education, Department of General Science, Zakho, Iraq \\ ${ }^{4}$ Erbil Polytechnic University, Technical Institute in Khabat, Department of Plant Protection, Erbil, Iraq \\ ORCID ID: Azhar Mohammed AL-KHAZALI: https:// orcid.org/0000-0001-7268-696X; Fenik Sherzad HUSSEN: https:/ /orcid.org/0000-0001- \\ 8748-0470; Hamid Saeid KACHEL: https://orcid.org/0000-0002-7231-8267; Noora Khalid ISMAIL: https:/ /orcid.org/0000-0001-6061-6999; \\ Ayoub Ibrahim AHMED: https://orcid.org/0000-0002-0005-8136
}

\begin{tabular}{llll}
\hline Received: 15.11 .2021 & Accepted: $29.12 .2021 \quad$ Published online: $30.12 .2021 \quad$ Issue published: 31.12 .2021
\end{tabular}

\begin{abstract}
The Iraqi spider fauna includes several dozens of species described and reported mostly by local researchers but still there are considerable sampling gaps. For the first time in Iraq, Agelena orientalis C. L. Koch 1837 (Agelenidae), Oxyopes globifer Simon, 1876 (Oxyopidae), and Thanatus formicinus (Clerck, 1757) (Philodromidae) are recorded. In addition, newly collected material of Bassaniodes tristrami (O. Pickard-Cambridge, 1872) (Thomisidae) and Eusparassus mesopotamicus Moradmand \& Jäger, 2012 (Sparassidae) are also presented. The characteristic features, habitus and copulatory organs of all species are presented here along with their geographic distribution.
\end{abstract}

Keywords: Grass spiders, lynx spider, crab spiders, huntsman spider, first records.

\section{Irak Örümcek Faunası için Üç Yeni Kayıt ve İki Kayıt Doğrulaması}

\begin{abstract}
Öz: Irak örümcek faunası, çoğunlukla yerel araştırmacılar tarafından tanımlanan ve rapor edilen birkaç düzine türü içerir fakat yine de birçok örneklenmemiş alan bulunmaktadır. Irakta ilk kez Agelena orientalis C. L. Koch 1837 (Agelenidae), Oxyopes globifer Simon, 1876 (Oxyopidae), ve Thanatus formicinus (Clerck, 1757) (Philodromidae) kayıt edilmiştir. Buna ilaveten Bassaniodes tristrami (O. Pickard-Cambridge, 1872) (Thomisidae) ve Eusparassus mesopotamicus Moradmand \& Jäger, 2012 (Sparassidae) türlerinin yeni toplanan örnekleri sunulmuştur. Tüm türlerin karakteristik özellikleri, habitatları ve üreme organları, coğrafi dağılımları ile birlikte burada sunulmuştur.
\end{abstract}

Anahtar kelimeler: Huni ağ örümcekleri, vaşak örümceği, yengeç örümcekleri, avcı örümceği, ilk kayıtlar.

\section{Introduction}

Araneae Clerck, 1757 is the largest order of arachnids with 4219 genera and 49583 described species around the world (World Spider Catalog, 2021). Still, the knowledge on diversity and distribution of spider fauna of Iraq is sparse, especially in comparison to the other countries of the Middle East. The most recently list of Iraqi spiders is that of Fomichev et al. (2018) who listed only 53 species belonging to 42 genera and 22 families. During the threeyear period following that publication, several papers (e.g. Al-Khazali, 2018, 2020, Al-Khazali \& Najim, 2018; AlKhazali \& Jäger, 2019; Najim et al., 2019; Al-Khazali \& Fomichev, 2021) have reported data and new records of spiders as a result of which the number of Iraqi spider species has risen to 61 .

The aim of the present study is to present records of three species new to the list of Iraqi spiders and additional distribution records of two species based on the new material collected in northern and southern Iraq.

\section{Material and Methods}

All specimens were collected from three different provinces: Dohuk, Erbil (both in northern Iraq) and Dhi
Qar (southern Iraq) (Fig. 1). The specimens were deposited at the College of Basic Education, University of Sumer, Dhi Qar, Iraq. Spiders were preserved in $75 \%$ ethanol and examined using a Nikon camera connected to a dissecting microscope. The epigynes were cleared in a $\mathrm{KOH} /$ water solution until the soft tissues were dissolved. Photographs of the copulatory organs were taken in a dish with white cotton at the bottom, filled with alcohol. Identification of specimens depended on comparison with figures of Levy (1996, 1999, 1976), Logunov (1996), Szita and Samu (2000), and Moradmand and Jäger (2012). The measurements of legs are provided as total length (femur, patella, tibia, metatarsus, and tarsus). All measurements are in millimeters. The Iraq map that was used in this study obtained from the website Country Wise Codes.

\section{Results}

Family: Agelenidae C. L. Koch, 1837

Genus: Agelena Walckenaer, 1805

Agelena orientalis C. L. Koch, 1837 (Fig. 2a-c)

Agelena orientalis: Levy, 1996: 86, f. 4-8.

Material examined: 2 우, Iraq, Dohuk Province, Zakho 
District, agricultural region, $37.139336^{\circ} \mathrm{N} 42.707545^{\circ} \mathrm{E}, 2$. Apr.2020, leg. H. S. Kachel.

\section{Determination: Levy, 1996.}

Diagnosis: The female of this species is very similar to A. labyrinthica; however, it can be distinguished by the shape of the epigynal septum, the posterior edge of the epigyne, and the shape and position of the spermathecae (see Levy, 1996; figs. 7-8).

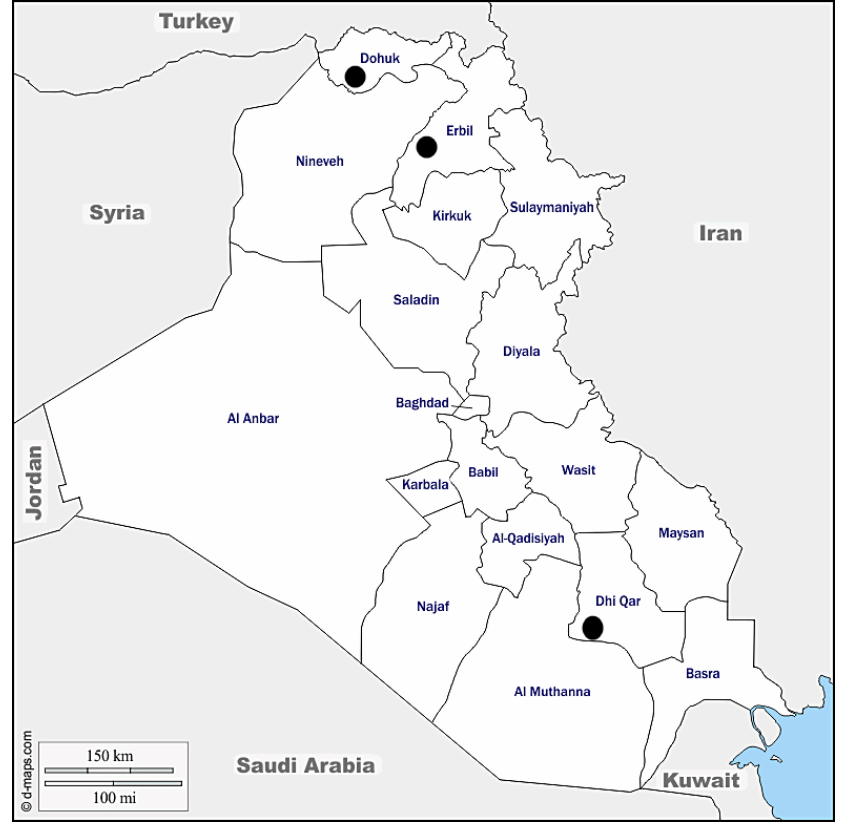

Figure 1. Map of Iraq showing specimens sampling localities: Dohuk, Erbil, and Dhi Qar provinces (dark circles).

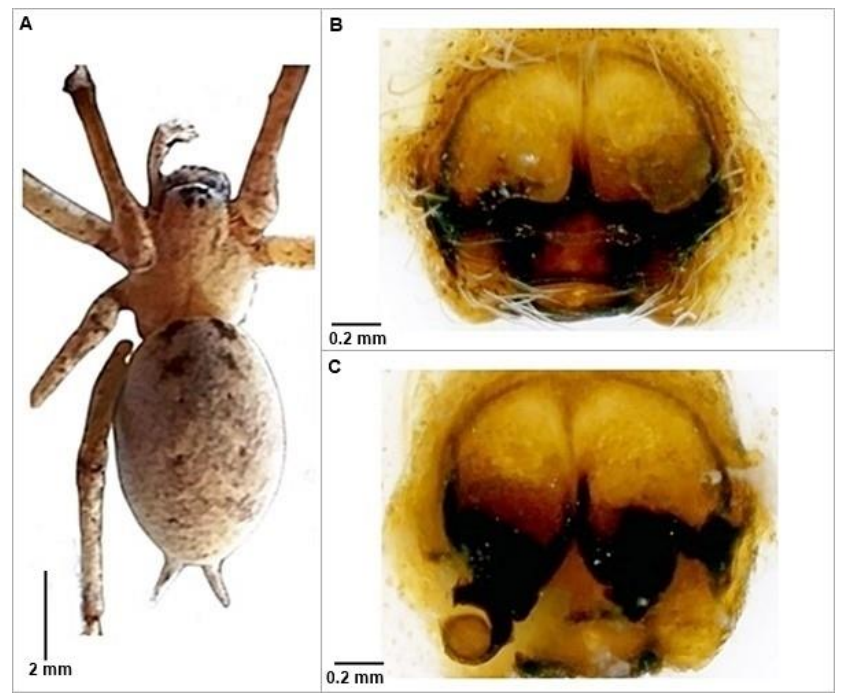

Figure 2. Agelena orientalis C. L. Koch, 1837, female; A. Habitus (live specimen), dorsal view; B-C. Epigyne, ventral and dorsal views respectively.

Description of female: General appearance as in Fig. 2a. Measurements: Body length 8.87; carapace 6.65 long, 5.02 wide; opisthosoma 8.08 long, 4.40 wide. Leg measurements: I: 20.56 (6.01, 1.50, 5.02, 5.65, 2.38), II: 20.35 (6.10, 1.78, 4.72, 5.34, 2.41), III: 19.52 (6.07, 1.40, 5.14, 4.68, 2.23), IV: 22.03 (7.72, 1.51, 5.47, 4.95, 2.38). General coloration brown-yellow, carapace yellow, brownish frontally, covered with fine setae. Sternum and coxae pale yellow, maxillae and chelicerae brown. Opisthosoma elongated and expanded in the middle part, dorsally yellow with thin brown stripes at the top, covered with fine setae, ventrally pale yellow. Spinnerets brownish. Legs uniform yellow.

General distribution: Widely distributed, from Italy to Central Asia, Iran (World Spider Catalog, 2021), and Iraq (current paper).

\section{Family: Oxyopidae Thorell, 1869}

Oxyopes globifer Simon, 1876 (Fig. 3a-d).

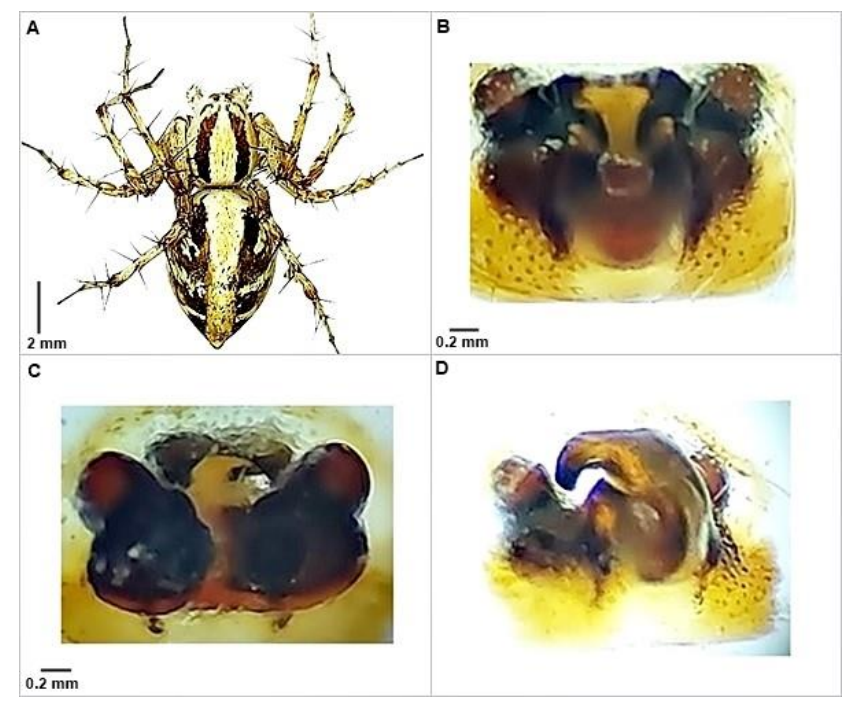

Figure 3. Oxyopes globifer Simon, 1876, female; A. Habitus (live specimen), dorsal view; B-D. Epigyne, ventral, dorsal and retrolateral views respectively.

Material examined: 2 우, Iraq, Dhi Qar Province, AL-Nassr District, from the outside wall of my house, $31.534582^{\circ} \mathrm{N}$ $46.120739^{\circ} \mathrm{E}, 12 \mathrm{~m}$ a.s.l. (Fig. 1), 2. July. 2021, leg. A. M. AlKhazali.

Determination: Levy (1999).

Diagnosis: The female of $O$. globifer can be recognized from congeners by having a strong laterally extending median protrusion of the epigyne (Fig. 3b-d).

Description of female: General appearance as in Fig. 2a. Measurements: Body length 8.87; carapace 3.21 long, 2.34 wide; opisthosoma 5.66 long, 3.15 wide. Leg measurements: I: 9.95 (2.79, 0.81, 2.33, 2.64, 1.38), II: 3.56 (2.59, 1.02, 2.15, 2.60, 1.06), III: 6.43 (2.12, 0.77, 1.45, 2.03, 0.76), IV: 10.78 (3.32, 1.22, 2.23, 3.07, 0.94). Carapace elongated, light-yellow in the midline, with a wide reddish-brown strip on each lateral side, the outer edges light-yellow, covered with fine setae. Sternum, labium, maxillae and chelicerae light yellow. Opisthosoma oval, with a semi-pointed end, dorsal coloration as in carapace, laterally with a pattern of three pairs of light-grey stripes, ventrally yellow with small pale spots on sides, with a broad, pale brown medial stripe. Spinnerets yellow. Legs uniform reddish yellow.

General distribution: This species distributed in Southern Spain, Greece, Kazakhstan, Turkmenia, Uzbekistan, Tadzhikistan, Turkey, Israel, Egypt, Algeria, Tunisia, Libya (Levy, 1999), Iran (Zamani et al, 2015), and Iraq (current paper).

Family: Philodromidae Thorell, 1870

Genus: Thanatus C. L. Koch, 1837 
Thanatus formicinus (Clerck, 1757) (Fig. 4a-c)

Determination: Logunov (1996), Szita \& Samu (2000).

Specimens examined: 2 우, Iraq, Erbil Province, Zanko Village, agricultural land, $36.190073^{\circ} \mathrm{N}, 43.993030^{\circ} \mathrm{E}, 12 \mathrm{~m}$ a.s.l. (Fig. 1), 15. Feb. 2020, leg. F. S. Hussein.

Diagnosis: See Logunov (1996).

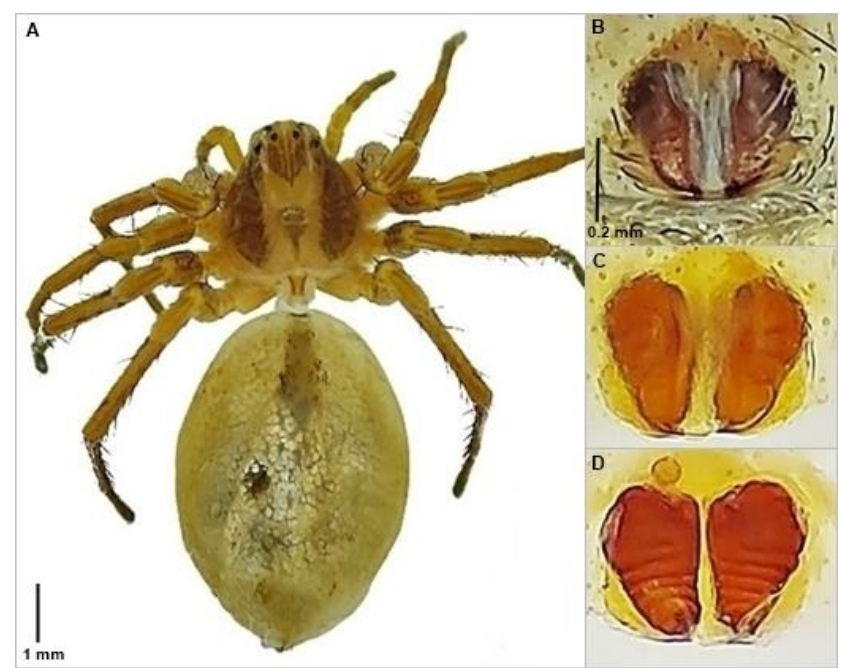

Figure 4. Thanatus formicinus (Clerck, 1757), female; A. Habitus, dorsal view; B, C. Epigyne, ventral view (A, after maceration in $\mathrm{KOH})$, D. dorsal view.

Description of female: General appearance as in Fig. 4a. Measurements: Body length 8.6; prosoma 3.83 long, 2.87 wide; opisthosoma 4.77 long, 3.62 wide. Leg measurements: I: 4.28 (1.30, 0.47, 1.12, 1.01, 0.38), II: 4.96 (1.44, 0.43, 1.33, 1.05, 0.71), III: 4.09 (1.52, 0.36, 1.42, 0.98, $0.62)$, IV: $5.83(1.72,0.56,1.22,1.45,0.88)$. The general coloration brownish yellow to light reddish brown, carapace brownish, with a pair of wide longitudinal brown bands, covered with fine setae. Ocular area mostly light reddish. Legs, coxae and sternum reddish brown, maxillae and chelicerae light brown. Opisthosoma oval, brownish yellow, dorsum with clear reddish brown cardiac strip extending from the anterior to the middle, covered with fine brownish setae, ventrally pale brownish. Spinnerets brownish yellow.

General distribution: North America, Europe, North Africa, Turkey, Caucasus, Russia (Europe to Far East), Iran, Kazakhstan, Central Asia, China, Japan (World Spider Catalog, 2021), and Iraq (current paper).

\section{Family: Thomisidae Sundevall, 1833}

Genus: Bassaniodes Pocock, 1903

Bassaniodes tristrami (O. Pickard-Cambridge, 1872) (Fig. 5. a-c)

Xysticus tristrami Kiany et al., 2017: 7, f. 14a-c (ふ઼).

Bassaniodes tristrami Breitling, 2019: 203.

B. tristrami Naumova, 2020: 5, f. 9-11 (ふ઼).

Determination: Levy (1976), Dippenaar-Schoeman (1989), Kiany et al. (2017)

Specimens examined: $1 \hat{\jmath}$ and $1 \hat{\jmath}$ subadult, Northern Iraq, Dohuk Province, Zakho district, agricultural land, under dry mud piles, $37.139336^{\circ} \mathrm{N}, 42.707545^{\circ} \mathrm{E}, 12 \mathrm{~m}$ a.s.l. (Fig.

\section{1), 2. Mar. 2020, leg. H. S. Kachel.}

Diagnosis: See Levy (1976) and Kiany et al. (2017).

General distribution: Greece, Turkey, Caucasus, Russia (Europe) to Central Asia, Middle East (World Spider Catalog, 2021), Kyrgyzstan, Tajikistan (Mikhailov, 2013), and Iraq (current paper).

Distribution in Iraq: Dohuk province.

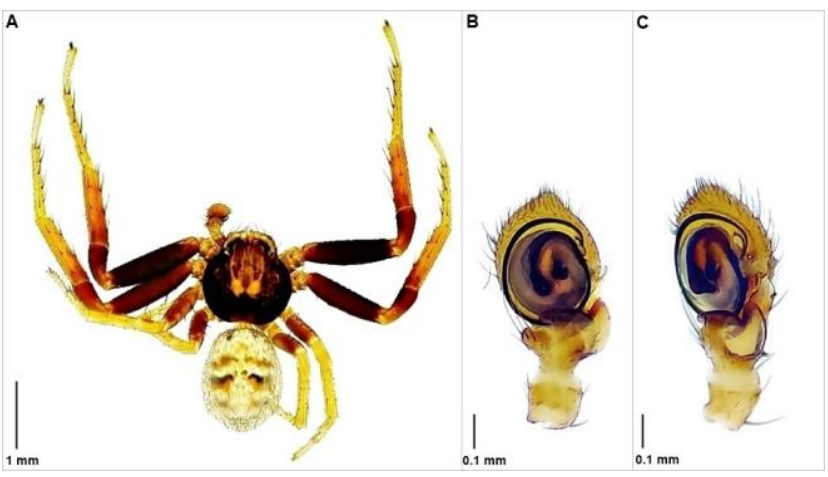

Figure 5. Bassaniodes tristrami (O. Pickard-Cambridge, 1872), male; A. Habitus, dorsal view; B, C. Palp, ventral and nearly retrolateral views.

Comments: This species was recorded in Iraq for the first time by Fomichev et al. (2018) under the genus Xysticus based on material collected from Dohuk province, northern Iraq.

\section{Family: Sparassidae Bertkau, 1872}

Genus: Eusparassus Simon, 1903

Eusparassus mesopotamicus Moradmand \& Jäger, 2012 (Fig. 6a-d)

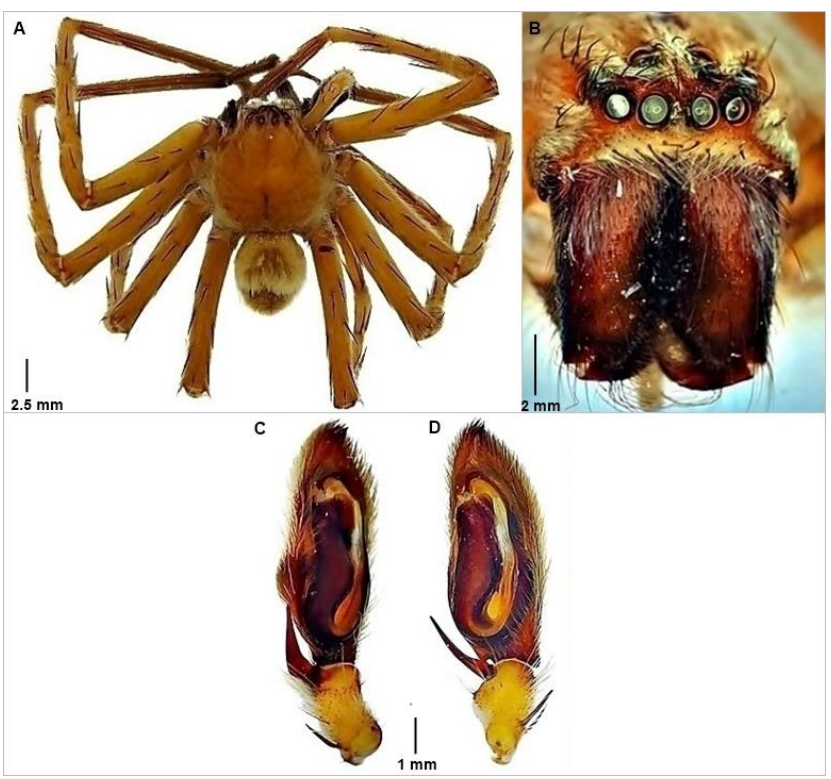

Figure 6. Eusparassus mesopotamicus Moradmand \& Jäger, 2012, male; A. Habitus, dorsal view; B. Prosoma, nearly anterior; C, D. Palp, ventral and retro-ventral views.

Determination: Moradmand \& Jäger, (2012), Moradmand, (2013).

Specimens examined: $2 \hat{\jmath} \hat{\jmath}$, southern Iraq, Dhi Qar Province, AL-Nassr district, From inside a rural house, $31.534582^{\circ} \mathrm{N}$ 
$46.120739^{\circ} \mathrm{E}, 12 \mathrm{~m}$ a.s.l. (Fig. 1), 10. July. 2020, leg. A. M. AlKhazali.

Diagnosis: See Moradmand \& Jäger (2012).

General distribution: Known from Iran, Iraq, and Turkey (World Spider Catalog, 2021).

Distribution in Iraq: AL-Najaf and Dhi Qar provinces.

Comments: According Moradmand \& Jäger (2012), only one female was collected from AL-Najaf province in Iraq, in the current study two males were collected from Dhi Qar province, southern Iraq.

\section{Discussion}

According to the recent data, there are approximately 61 species of Iraqi spiders known so far (AL-Khazali, 2020). The present findings represent the first records of three species of spiders: Agelena orientalis C. L. Koch 1837, Thanatus formicinus (Clerck, 1757), and Oxyopes globifer Simon, 1876 in Iraq and the last two also represent the first records of these genera. Thus, the number of species within spider fauna of Iraq has risen to 64 known species. However, the spider fauna of Iraq is still poor when it is compared with some neighboring countries such as Iran that contains 780 known species (Zamani et al., 2020) and Turkey where there are 1129 known species (Demir \& Seyyar, 2017; Danışman et al., 2021). This is due to the scarcity of studies and researchers interested in this group of arachnids. It is expected to find many other species of spiders in Iraq due to the fact that many regions are still not studied at all and; therefore, any material collected from those regions are expected to include new records of spider species and genera. Bassaniodes tristrami (O. Pickard-Cambridge, 1872) was recorded for the first time in Iraq under genus Xysticus by Fomichev et al. 2018 where three males were collected from Dohuk Province, north foothill of Chiaje-Spizakho-Dag Mountain Range. Both males in this study were found in another place in the same Dohuk Province but it is a geographically different region (agricultural land) to the previous study by Fomichev et al. (2018); no female was found so far. In this study, two male E. mesopotamicus specimens were collected from Dhi Qar province, which is a new locality for this species in southern Iraq, despite Moradmand and Jäger reporting a single female of this species from AL-Najaf province in central Iraq (2012).

Therefore, according to the current study as well as the previous studies interested in Iraqi spiders, it can be concluded that this group of arachnids is still very poor, especially when compared with some neighboring countries such as Iran and Turkey. Fomichev et al. (2018) indicated that the number of species may not exceed $10 \%$ of the actual number of spider species in Iraq. In this regard and to increase knowledge about the spider fauna of Iraq, more arachnological studies of this country must be conducted.

Acknowledgements: We thank Alireza ZAMANI (University of Turku, Finland) for providing scientific advice and confirming the identity of species. We express our gratitude to the anonymous reviewers for their valuable scientific and technical notes.

Ethics committee approval: Ethics committee approval is not required for this study.
Conflict of interest: The authors declare that there is no conflict of interest.

\section{References}

Al-Khazali, A.M., \& Najim, S.A. (2018). First records of Pholcidae (Arachnida, Araneae) from Iraq. Bulletin of the Iraq Natural History Museum, 15(2), 179-187. https://doi.org/10.26842/binhm.7.2018.15.2.0179

Al-Khazali, A.M. (2018). The first record of family Agelenidae from Iraq (Arachnida: Araneae). Serket, 16(2), 60-65.

Al-Khazali, A.M., \& Jäger, P. (2019). Cebrennus sumer sp. nov. (Araneae: Sparassidae): first record of the genus in Iraq. Arachnology, 18(1), 37-39. https://doi.org/10.13156/arac.2018.18.1.37

AL-Khazali, A.M. (2020). Genus Hogna Simon, 1885 (Araneae: Lycosidae), a new record to the spider fauna of Iraq. Serket, 17(2), 101-104.

Al-Khazali, A.M., \& Fomichev, A.A. (2021). Description of the female of Berlandina mesopotamica (Araneae: Gnaphosidae). Arachnologische Mitteilungen 61, 70-72. https:/ / doi.org/10.30963/aramit6111

Danışman, T., Kunt, K.B., \& Özkütük, R.S. (2021). The Checklist of the Spiders of Turkey. Version 2019, Retrieved from http://www.spidersofturkey.info

Demir, H., \& Seyyar, O. (2017). Annotated checklist of the spiders of Turkey. Munis Entomology \& Zoology, 12(2), 433-469.

Dippenaar-Schoeman, A.S. (1989). An annotated check list of crab spiders (Araneae: Thomisidae) of Saudi Arabia. Fauna Saudi Arabia, 10, 20-30.

Fomichev, A.A, Marusik, Y.M., \& Koponen, S. (2018). New data on spiders (Arachnida: Araneae) of Iraq. Zoology in the Middle East, 64(4), 329-339.

Kiany, N., Sadeghi, S., Kiany, M., Zamani, A., \& Ostovani, S. (2017). Additions to the crab spider fauna of Iran (Araneae: Thomisidae). Arachnologische Mitteilungen, 53, 1-8.

Levy, G. (1976). The spider genus Xysticus (Araneae: Thomisidae) in Israel. Israel Journal of Zoology, 25, 1-37.

Levy, G. (1996). The agelenid funnel-weaver family and the spider genus Cedicus in Israel (Araneae, Agelenidae and Cybaeidae). Zoologica Scripta, 25(2), 85-122. https://doi.org/10.1111/j.1463-6409.1996.tb00154.x

Levy, G. (1999). The lynx and nursery-web spider families in Israel (Araneae, Oxyopidae and Pisauridae). Zoosystema, 21, 29-64.

Logunov, D.V. (1996). A critical review of the spider genera Apollophanes O. P.-Cambridge, 1898 and Thanatus C.L. Koch, 1837 in North Asia (Araneae, Philodromidae). Revue Arachnologique, 11(13), 133-202.

Mikhailov, K.G. (2013). The spiders (Arachnida: Aranei) of Russia and adjacent countries: a non-annotated checklist. Arthropoda Selecta, Supplement 3. Moscow, KMK Scientific Press., 260 pp.

Moradmand, M., \& Jäger, P. (2012). Taxonomic revision of the huntsman spider genus Eusparassus Simon, 1903 (Araneae: Sparassidae) in Eurasia. Journal of Natural History, 46(39-40), 2439-2496. https://doi.org/10.1080/00222933.2012.707249

Moradmand, M. (2013). The stone huntsman spider genus Eusparassus (Araneae: Sparassidae): systematics and zoogeography with revision of the African and Arabian species. Zootaxa, 3675, 1-108. https://doi.org/10.11646/zootaxa.3675.1.1

Najim, S. A., Seyyar, O., \& Demir, H. (2019). Second record of Hippasa pisaurina Pocock, 1900 (Araneae: Lycosidae) from Iraq. Serket, 16(4), 188190.

Szita, É., \& Samu, F. (2000). Taxonomical review of Thanatus species (Philodromidae, Araneae) of Hungary. Acta Zoologica Academiae Scientiarum Hungaricae, 46, 155-179.

World Spider Catalog (2021). World Spider Catalog. Version 20.0. Natural History Museum Bern. Retrieved from http://wsc.nmbe.ch.

Zamani, A., Mirshamsi, O., Jannesar, B., Marusik, Y.M., \& Esyunin, S.L. (2015). New data on spider fauna of Iran (Arachnida: Araneae), Part II. Zoology and Ecology, 25(4), 339-346. https:// doi.org/10.1080/21658005.2015.1068508

Zamani, A., Mirshamsi, O., Marusik, Y.M., \& Moradmand, M. (2020). The checklist of the spiders of Iran, version 2020, Retrieved from http://www.spiders.ir 